\title{
LANDSAT CAPABILITY TO MAPPING OF TOTAL SOLID SUSPENDED (TSS) AND COASTAL ECOSYSTEM
}

\author{
Nurjannah Nurdin ${ }^{1,4}$, Muhammad Helmi ${ }^{2}$, Riza Yuliratno Setiawan ${ }^{3}$, Mukti Zainuddin ${ }^{1}$, Rustam ${ }^{1}$, Agus $^{4}$, M. Akbar AS $^{4}$ \\ ${ }^{1}$ Marine Science and Fisheries Faculty, Hasanuddin University, Makassar, 90245. Indonesia. nurj_din@ yahoo.com \\ ${ }^{2}$ Marine Science and Fisheries Faculty, Diponegoro University, Semarang, 1269. Indonesia \\ ${ }^{3}$ Marine Science and Fisheries Faculty, Gadjah Mada University, Yogyakarta, 55281. Indonesia \\ ${ }^{4}$ Research and Development Center for Marine, Coast, and Small Island, Hasanuddin University, Jl.Perintis Kemerdekaan \\ km.10, Makassar, 90245. Indonesia. nurj_din@yahoo.com
}

KEY WORDS: TSS, Landsat, Spermonde Archipelago

\begin{abstract}
:
The purpose of this study was to analyze the distribution dynamics and TSS concentrations based on four different seasons and different years for five years. Image processing of TSS included Correction with Dark Object Substraction and Atmospheric correction method, and Syarif Budhiman algorithm used to extract TSS. The image processing of coastal ecosystem was composed of eight main steps including: atmospheric correction, cropping, masking, depth invariant index, Unsupervised Classification, ground truthing, reclassify, and accuracy assessment. The distribution of suspended sediments is the highest and dominant content in the coastal area adjacent to the river estuary. In addition, based on quality standards for marine biota and TSS values for fisheries purposes, it can be revealed that the fertility of Spermonde coastal waters crosses the quality standard and is not good for fisheries activities.
\end{abstract}

\section{INTRODUCTION}

The waters of the Spermonde Islands are influenced by several factors that cause changes in physical, chemical and biological conditions. Factors from land that affect water conditions are human activities such as settlement, transportation, industry, agriculture and mining. While the factors of the sea are tides, waves, and currents.

Utilization of remote sensing technology to detect sediments based on varying carasteristic properties of waves. Some waves are able to penetrate water and are reemitted by objects to sensors that penetrate the water medium. Detection is based on the principle of wave sensitivity (Li, Kaufman, Gao, \& Davis, 2003) which shows that some image bands respond to turbidity and sedimentation conditions.

Spermonde waters have two (2) downstream big river, all of the river flowing towards the Spermonde waters. This is the cause of sedimentation and pollution around of the downstream eiver. This condition will threaten biodiversity and sustainability coastal ecosystems in the waters Spermonde. The purpose of this study was to analyze the distribution dynamics and TSS concentrations based on 4 different seasons and different years for 5 years.

\section{MATERIAL AND METHODS}

\subsection{Field study}

This research was carried out in Spermonde waters in the inner zone and middle inner zone (Figure 1). Ground truthing locations are carried out in river estuaries such as the waters around the mouth of the Jeneberang River, Tallo River and several islands such as Pajenekang Island,
Sanane, Bontosua, Ballang Lompo and Ballang Caddi (Figure 1). Analysis of water samples was carried out at the Laboratory.

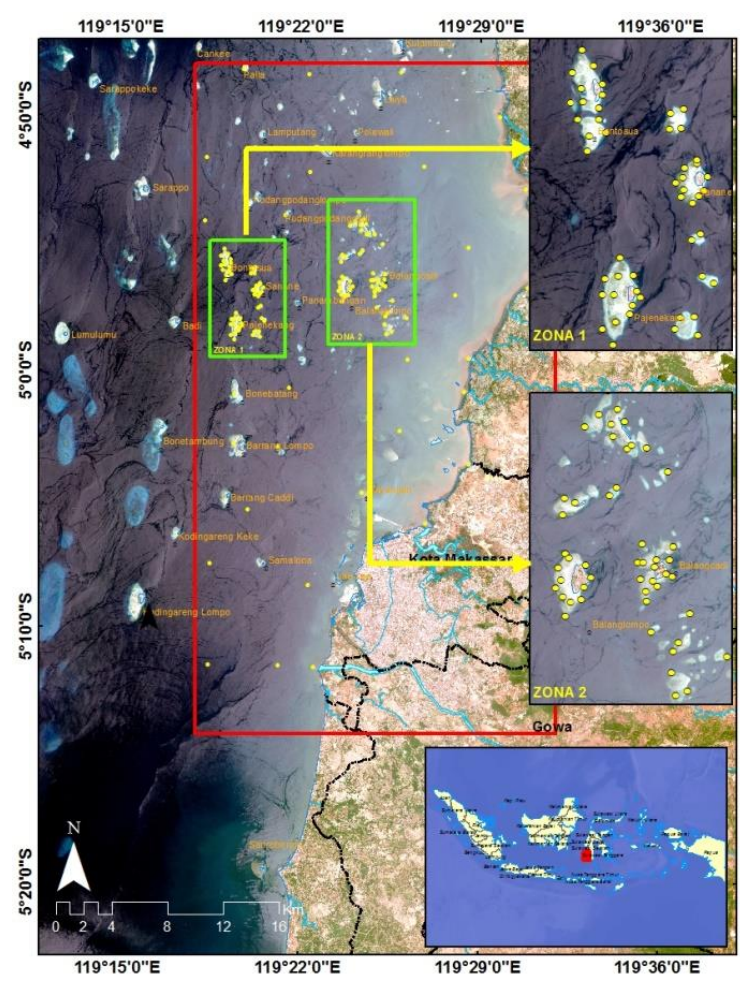

Figure 1. Spermonde water as a field location. Red line is border of Total Solid Suspended study area and yellow point is sampling point. 


\subsection{Data}

This study used Landsat $1,2,4,5,7$, and 8 with sensor MSS, TM, ETM, ETM+, OLI-TIRS to analysis coastal ecosystem. The Landsat-8 OLI imagery was multi temporal with path 114 row 63 in 2013, 2016, dan 2019 are used to analysis TSS. Satellite image data from the US Geological Survey ((http://earthexplorer.usgs.gov/)). The spatial analysis is processed using ArcGIS software.

\subsection{TSS in situ data processing}

Water sampling were taken from the field. It was calculated with the gravimetric method uses references from international standard methods namely standard methods for the examination of water and waste water (Indonesian Government Regulation No. 82 of 2001). The value of suspended solids can be obtained by equation as follows:

TSS $(\mathrm{mg} / \mathrm{l})=\mathrm{Wt}-\mathrm{Wo} \times 1000$

volume sampel awal $(\mathrm{ml})$

TSS $(\mathrm{mg} / \mathrm{l})=\mathrm{Wt}-\mathrm{Wo} \times 1000$

volume sampel awal $(\mathrm{ml})$

$\mathrm{Wt}=$ sample dry weight and residue after heating

$(\mathrm{mg}) ;$ Wo = Weight dry empty (mg).

\subsection{Image data processing}

\subsubsection{Image processing of TSS}

Landsat 8 OLI band data can also be converted to Top-ofAtmospheric(TOA) planetary reflectance using reflectance rescaling coefficients provided in the product metadata file (MTL file). The following equation is used to convert DN values to TOA reflectance for Landsat 8 OLI data (Hariyanto T, dkk.2017):

$$
\rho \lambda=\mathrm{M} \rho * \mathrm{Qcal}+\mathrm{A} \rho
$$

Where:

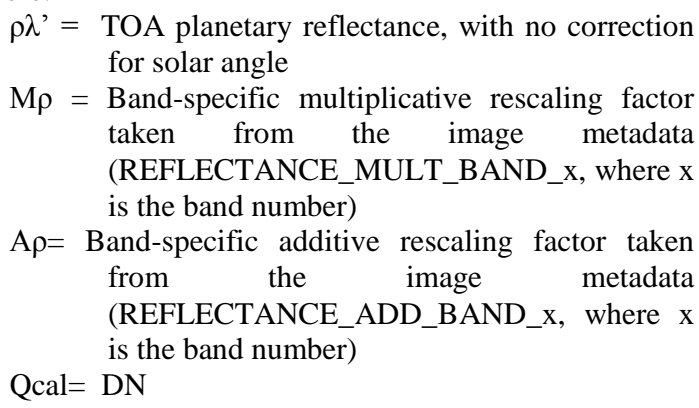

Correction with Dark Object Substraction (DOS) method is done by reducing the digital value of each channel, so that zero values are obtained for objects with reflections Lowest. Radiometric correction can be done with equations (Eastman, 1992):

$$
\mathrm{DN}=\text { Pixel value }-25 \text { (i1-25) }
$$

Where: $\mathrm{DN}=$ Corrected pixel value; $\mathrm{i} 1$ = Input 1

Absolute atmospheric correction procedures entail rectifying individual images in a time series using either empirical or radiative transfer-based approaches.
Empirical correction methods are mostly variants of DOS method (Chavez 1999; Song and Woodcock 2003).

Syarif Budhiman algorithm used to extract TSS. He is constructing a algorithm with red bands and irradiance reflectance values to determine the concentration of sediments in the waters. He is constructing a formula using red bands and irradiance reflectance values to determine the concentration of sediments in the waters.

$$
\operatorname{TSS}(\mathrm{mg} / \mathrm{l})=8.1429 * \operatorname{Exp}(23.704 * \text { Band Red })
$$

Red band $=$ reflectance value of band 4 Landsat produce seven classes of TSS variations. These results are in the range between 1-2000 $\mathrm{mg} / \mathrm{L}$. In Indonesia there are two seasons namely the rainy season and the dry season, but between these seasons there are transitional seasons from the west to the east and transition season from the east to the west.

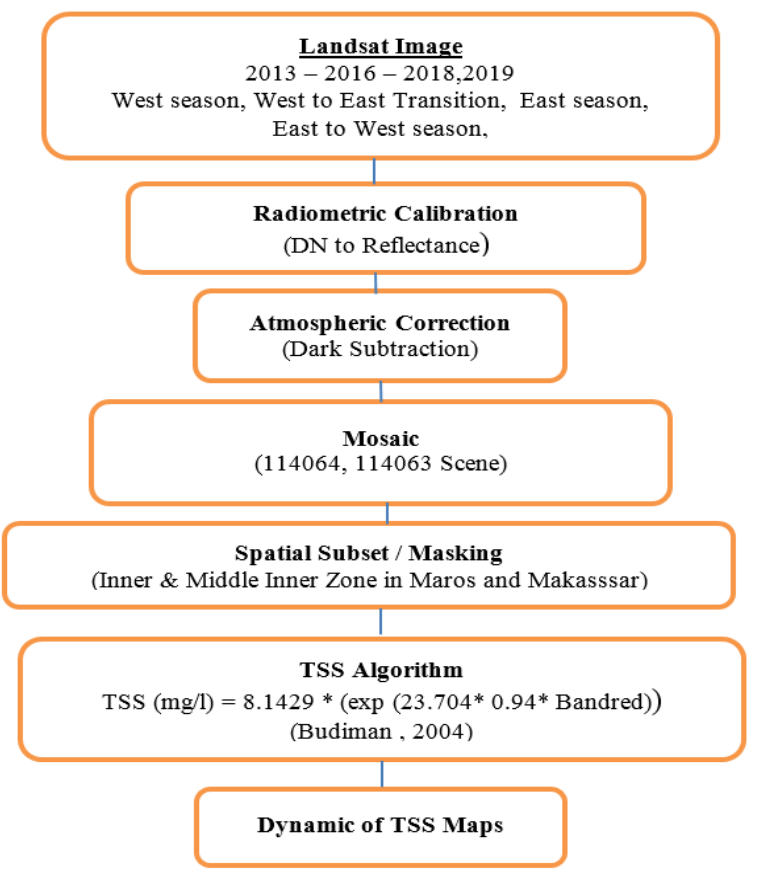

Figure 2. Flowchart of TSS analysis

\subsubsection{Image processing of coastal ecosystem}

The image processing of coastal ecosystem was composed of eight main steps including: atmospheric correction, cropping, masking, depth invariant index, Unsupervised Classification, ground truthing, reclassify, and accuracy assessment.

\section{RESULT}

The classification of Landsat MSS images in 1972 and Landsat 8 in 2016 is showing that shallow waters consist of six types of habitats. The live coral on Bontosua Island has decreased dramatically from 1972 to 2016. The decline of living coral is of $29.10 \mathrm{Ha}$ or $85.06 \%$, while the live coral on Ballang Caddi Island has experienced a dramatic decline from 1972 to 2016 around of 57.29 ha or $81.29 \%$. 

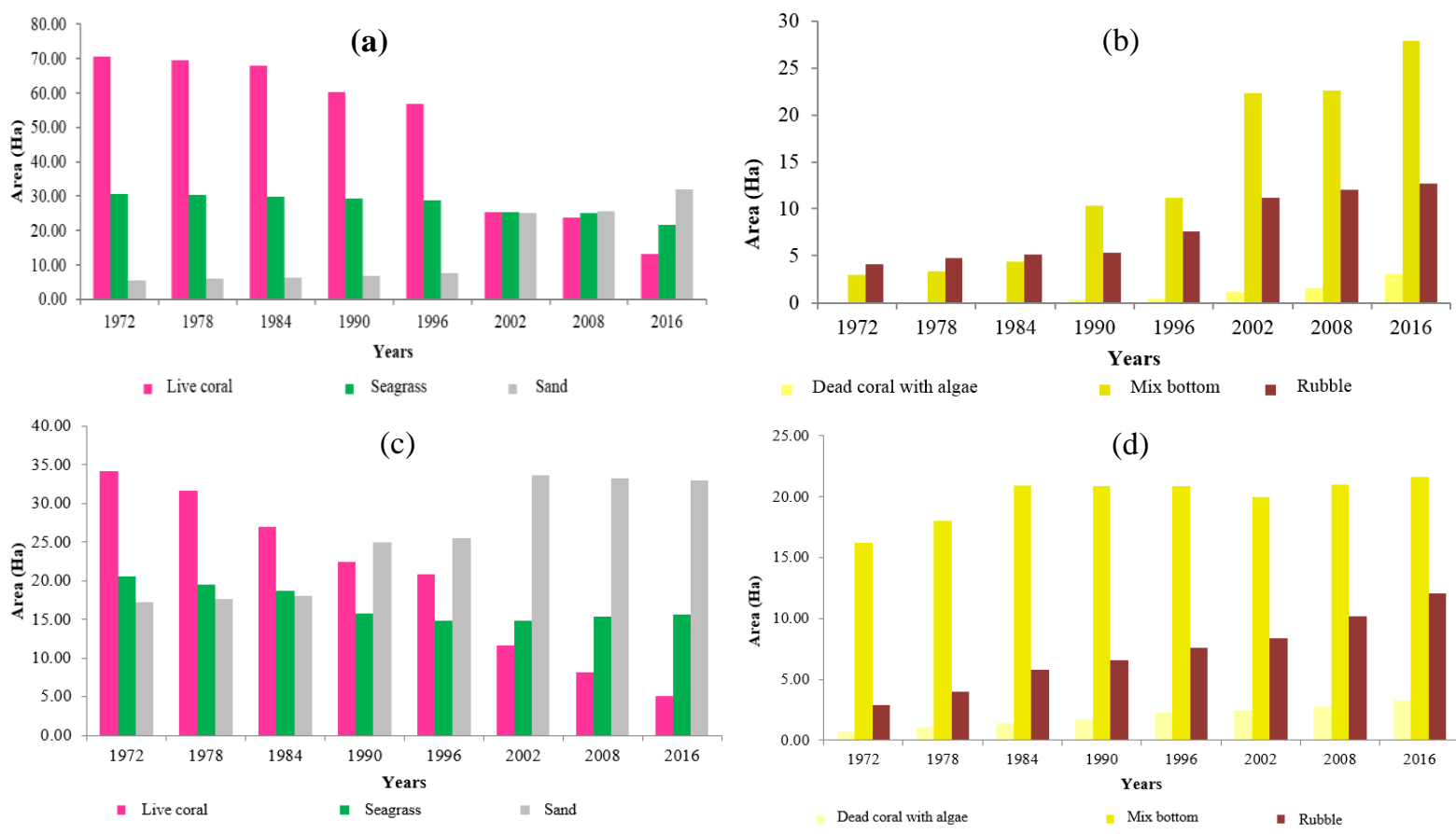

Figure 3. Graph of spatial dynamic of shallow water in Bontosua and Ballang Caddi island, (a) area of live coral, seagrass and sand in Ballang Caddi island, (b) area of dead coral with algae, mix bottom, and rubble in Ballang Caddi island, (c) area of live coral, seagrass and sand in Bontosua island, (b) area of dead coral with algae, mix bottom, and rubble in Bontosua island

Analysis of estimating TSS distribution is produce seven classes of TSS variations. These results are in the range between 1-2000 $\mathrm{mg} / \mathrm{L}$. In the research location, there are the rainy season and the dry season, from the west to the east and from the east to the west season (Figure 7,8,9,10). TSS Distribution in Spermonde Waters. It consists of four different seasons for 5 years (Figure 4,5,6). This spatial data is processed using ArcGIS software.

The highest TSS concentration is 146-234 $\mathrm{mg} / \mathrm{L}$ at Rainy season (west season, Dec-Feb)) in 2016 and 101-234 mg / L in 2018/2019, as shown in Figure 2. In addition / while in the dry season (east season, June-August) in 2013, the highest TSS concentration was between $52-58 \mathrm{mg} / \mathrm{L}, 38$ -
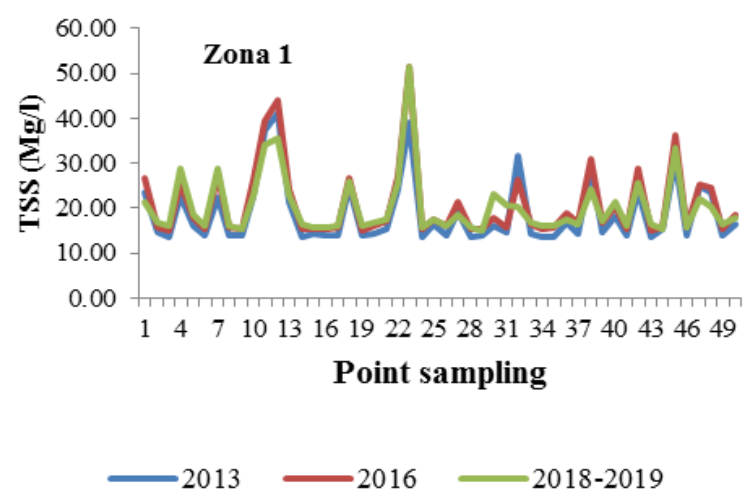

$50 \mathrm{mg} / \mathrm{L}$ in 2016 and $71-82 \mathrm{mg} / \mathrm{L}$ in 2018 / 2019. TSS distribution in both seasons shows almost the same conditions in the northern part of the outer zone and partly in the southern part of the inner zone of Spermonde waters.

In addition / while in the transition season from the east to the west (Sep-Nov) in 2013, the highest TSS concentration was between $39-43 \mathrm{mg} / \mathrm{L}$ and in 2016 it was $44-60 \mathrm{mg} / \mathrm{L}$, and in 2018 was $34-51 \mathrm{mg} / \mathrm{L}$. In addition / whereas in the transition season from the west to the east season (March-May) in 2013, the highest TSS concentration was between $98-110 \mathrm{mg} / \mathrm{L}$ and in 2016 it was $60-81 \mathrm{mg} / \mathrm{L}$, and in $2018 / 2-19$ is $43-49 \mathrm{mg} / \mathrm{L}$

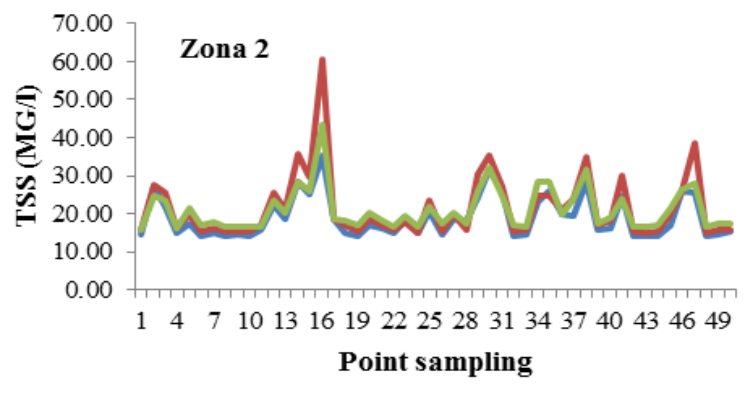

$-2013-2016-2018-2019$

Figure 4. TSS (Mg / 1) at each sampling point in Bontosua island as zone 1 and Ballang Caddi island as zone 2 Spermonde waters in the east to west season on September-November 2013, 2016, dan 2018-2019.. 


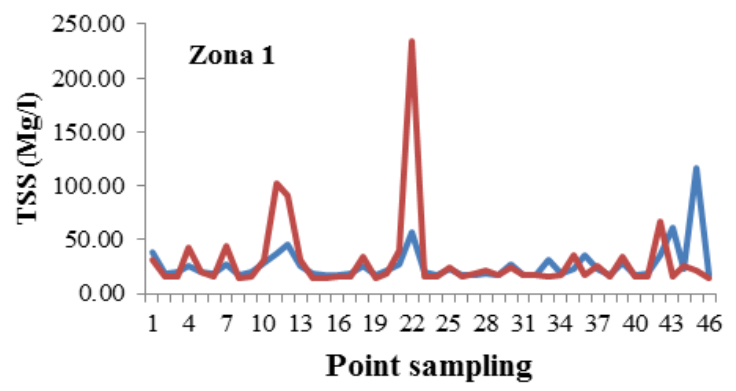

$-2016 \longrightarrow 2018-2019$

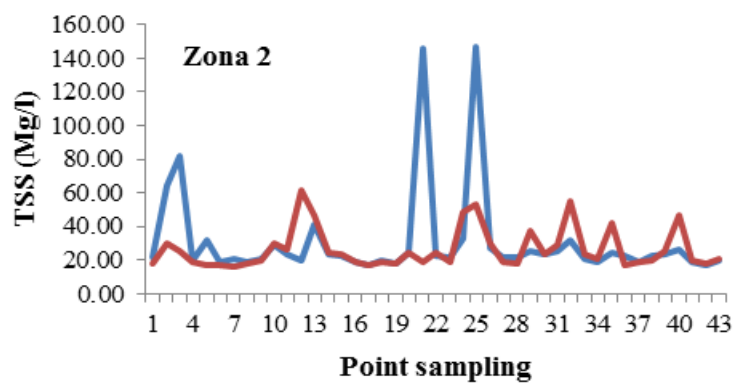

$2016 \longrightarrow 2018-2019$

Figure 5. TSS (Mg/1) at each sampling point in Bontosua island as zona 1 and Ballang Caddi as zona 2 Spermonde waters in the west season December-February 2016 and 2018-2019.
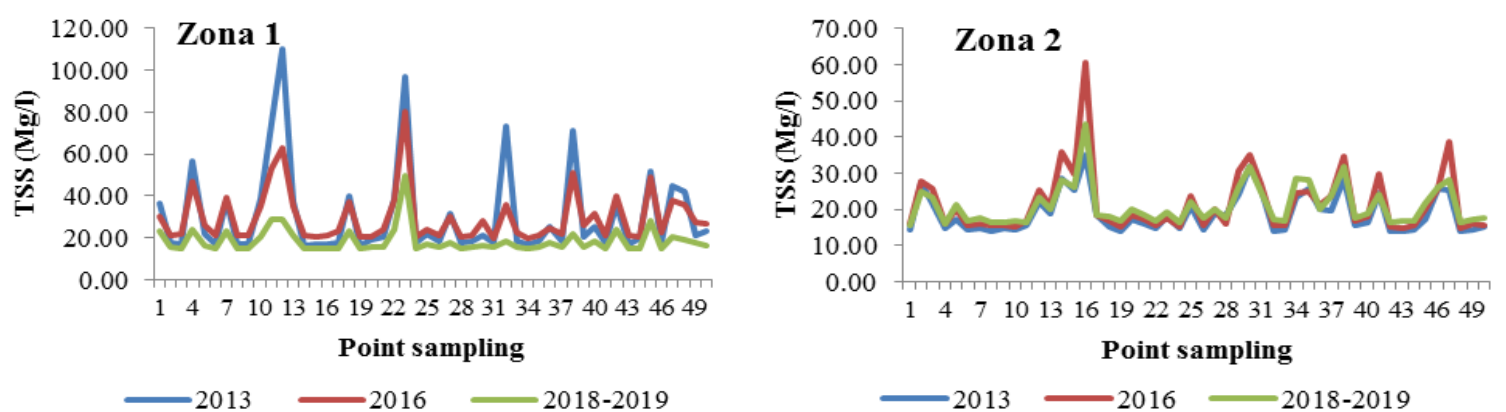

Figure 5. TSS (Mg/1) at each sampling point in Bontosua island as zona 1 and Ballang Caddi as zona 2 Spermonde waters in the west to east season on September-November 2013, 2016, dan 2018-2019

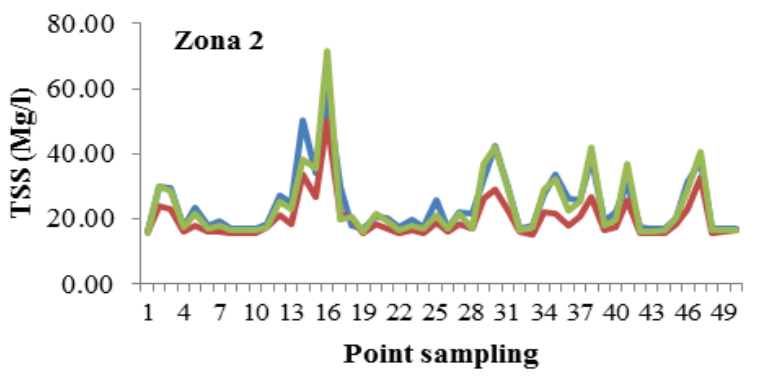

$2013 \longrightarrow 2016-2018-2019$

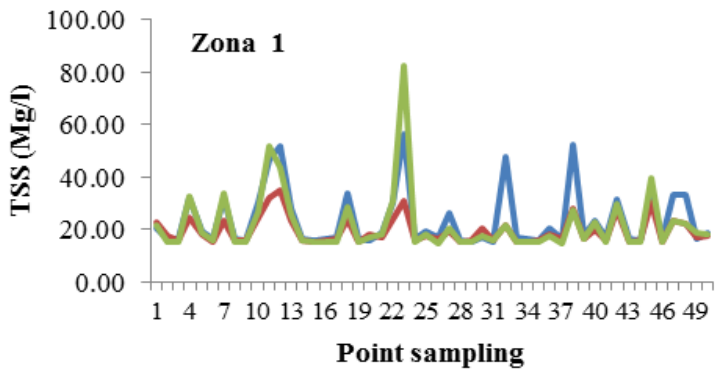

$-2013-2016-2018-2019$

Figure 6. TSS (Mg / 1) at each sampling point in Bontosua island as zona 1 and Ballang Caddi as zona 2, Spermonde waters in the east season on June-August 2013, 2016, and 2018-2019.

According to Government Regulation No. 822001 concerning processing of water quality and control of TSS value pollution based on the results of image processing shows that the TSS in raining season on December to February classified as not good. TSS distribution between raining and dry season are very different, namely TSS concentrations reached an average of more than one hundred $\mathrm{mg} / \mathrm{L}$ during the rainy season and less than 50 $\mathrm{mg} / \mathrm{L}$ during the dry season.

The silting contribution along the coast of the Spermonde waters is caused by activities occurred due to activities in several large watersheds such as Tallo river and Jeneberang river, as well as several small watershed others around which empties into the waters of Spermonde.

According to Government Regulation No. 822001 concerning processing of water quality and control of pollution of TSS values on in 2005 classified as not good and at 2015 is not good According to the Environmental Assessment report Life (SEA) 2012 mentions, in the last 13 years have occurred siltation Karang as wide as $1018 \mathrm{~m} 3$ and the depth of the sea ranges from $9 \mathrm{~m}$ up to 10 $\mathrm{m}$. The area of the bay is shrinking from originally 11860 $\mathrm{m}$ to $10840 \mathrm{~m}$ on in 2000 . This also supports with erosion conditions that occur in the Gulf Kendari, total sediment is based the source was in Kendari Bay in 2005 for erosion it reached 4,886,591.5 $\mathrm{m} 3$ while in 2010 for the erosion reach 5,150,182.4 m3 (City KLHS Kendari, 2012). The contribution of siltation of the Gulf Kendari is caused by activity 


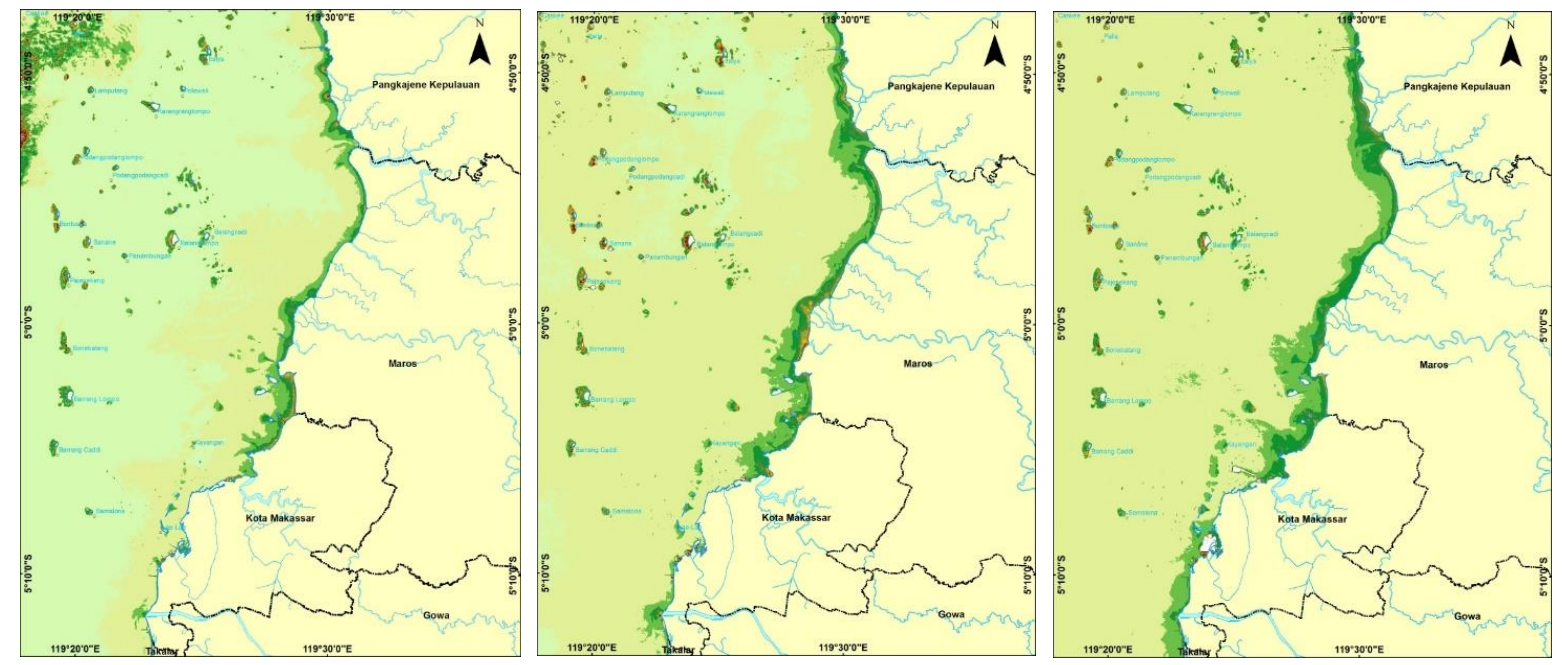

Figure 7. TSS distribution around Distribution around Bontosua and Ballang Caddi island and near from the main land and shore lines Spermonde waters in the transition season of the west season to the east season, (a) 2013, (b) 2016, (c) 2018-2019

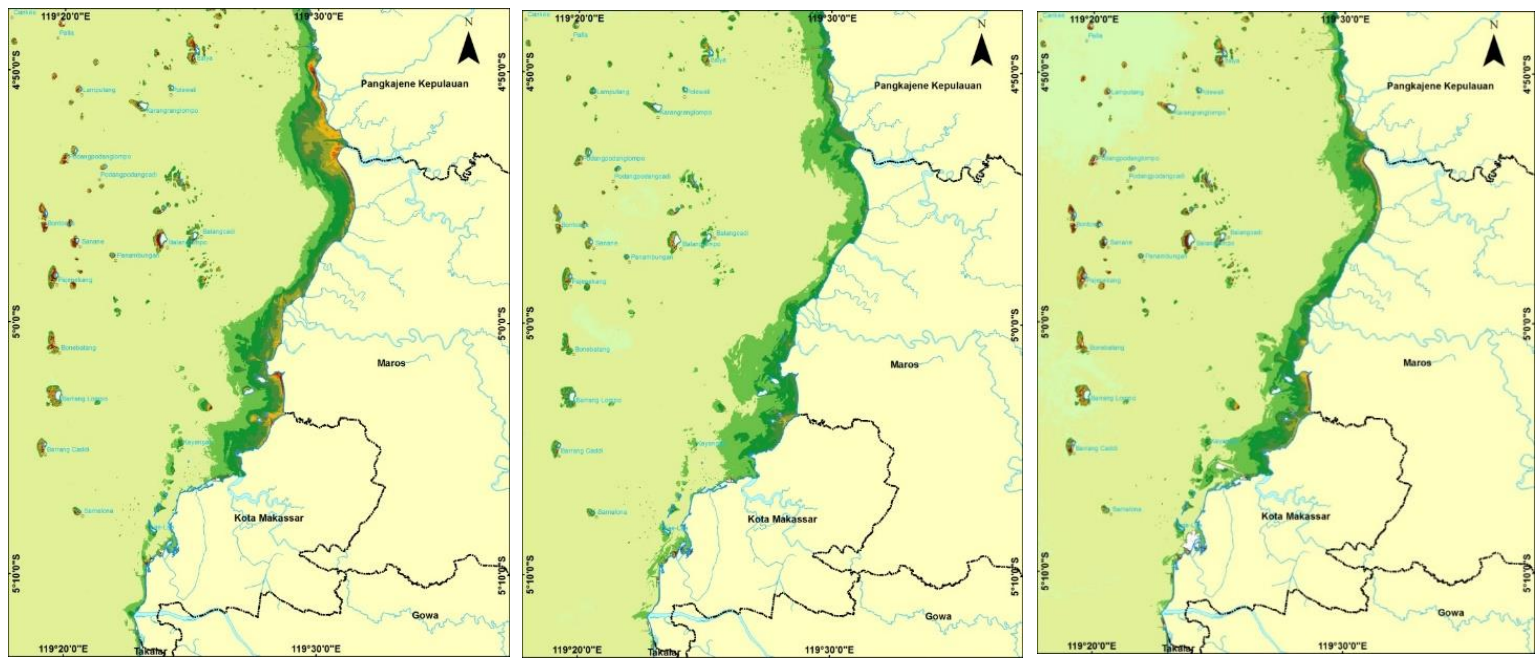

Figure 8. TSS Distribution around Bontosua and Ballang Caddi island and near from the main land and shore lines Spermonde waters in the east season, (a) 2013, (b) 2016, (c) 2018-2019.

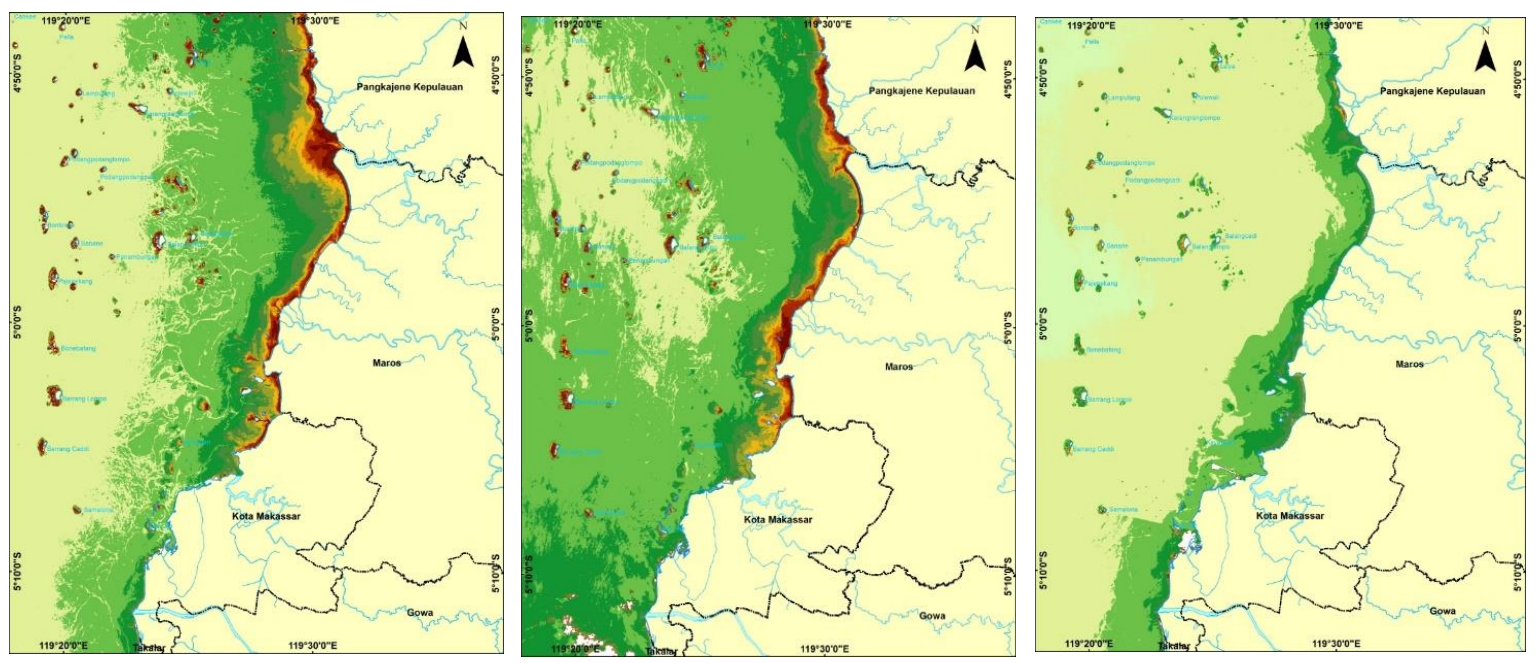

Figure 9. TSS distribution around Bontosua and Ballang Caddi island and near from the main land and shore lines in Spermonde waters in the transition season from east to west season, (a) 2013, (b) 2016, (c) 2018-2019. 


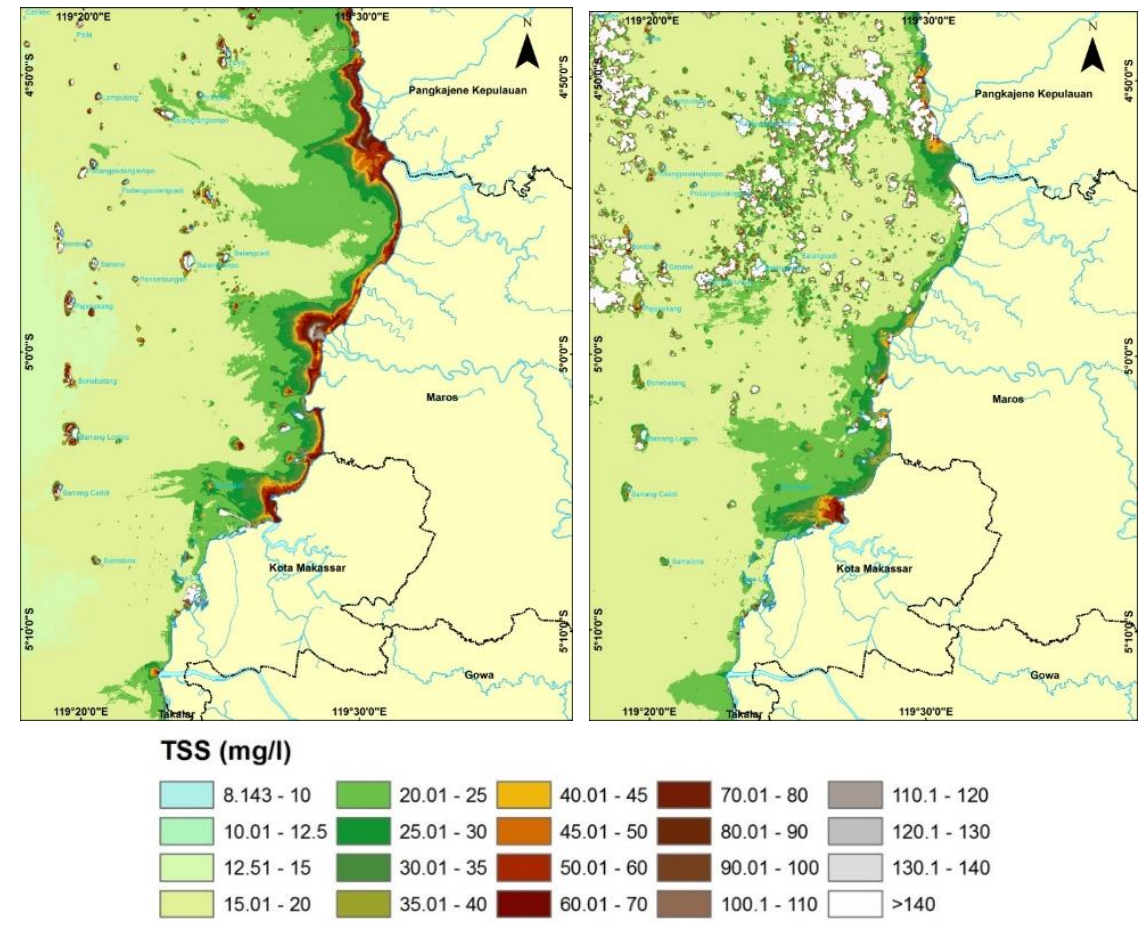

Figure 10. TSS distribution around Bontosua and Ballang Caddi island and near from the main land and shore lines in Spermonde waters in the western season December-February, (a) 2013, (b) 2016, (c) Years 2018-2019.

\section{CONCLUSION}

Based on the results and discussion in this study, it can concluded that Total distribution estimation results Suspended Solid (TSS) based on analysis of Landsat satellite imagery is divided into seven TSS distribution class ranges from 1-2000 $\mathrm{mg} / \mathrm{L}$ so that the map is obtained Thematic distribution of TSS in Spermonde waters with the highest TSS value every station 8 is in the estuary Wanggu River (2005) is equal to $131 \mathrm{mg} / \mathrm{L}$ in 2015 almost reaching more than $2000 \mathrm{mg} / \mathrm{L}$. The distribution of suspended sediments is the highest and dominant content in the coastal area adjacent to the river estuary. In addition, based on quality standards for marine biota and TSS values for fisheries purposes, it can be revealed that the fertility of Spermonde coastal waters crosses the quality standard and is not good for fisheries activities.

\section{ACKNOWLEDGEMENTS}

The authors would like to thank the Ministry of Research Technology and Higher Education of the Republic of Indonesia for the generous support in providing research funds. Thanks to Environmental Systems Research Institute (ESRI) Indonesia for software supporting.

\section{REFERENCES}

Budiman, 2004. In Syaiful Budianto dan Teguh Hariyanto. 2017. Analisis Perubahan Konsentrasi Total Suspended Solids (TSS) Dampak Bencana Lumpur Sidoarjo Menggunakan Citra Landsat Multi Temporal (Studi Kasus: Sungai Porong, Sidoarjo) JURNAL
TEKNIK ITS Vol. 6, No. 1, (2017) ISSN: 2337-3539 (2301-9271 Print)

Hariyanto,T. 2014. Identification of Total Suspended Sediment (TSS) Distribution at Surabaya East Coast Area in East

Java Indonesia Using TSS Algorithm Implementation on Multi Temporal Satellite Images, International Journal of Earth Sciences and Engineering ISSN 0974-5904, Vol. 07, No. 04, August, 2014, pp. 1341-1346

Teguh Hariyanto, Trismono C. Krisna, Khomsin, Cherie Bhekti Pribadi and Nadjadji Anwar. 2017. Developmentof Total Suspended Sediment Model using Landsat-8 OLI and In-situ Data at the Surabaya Coast, East Java, Indonesia. ISSN 2354-9114 (online), ISSN 0024-9521 (print) Indonesian Journal of Geography Vol. 49, No.1, June $2017 \quad(73-\quad 79) \quad$ DOI: http://dx.doi.org/10.22146/ijg.12010, website: https://jurnal8ugm.ac.id/ijg

Indira Rosvita Sari, Halili, La Ode Alirman Afu. 2017. The distribution of total suspended solid estimation based on satellite image data in

Kendari Bay. Sapa Laut Februari 2017. Vol. 2 (1): 1-7

KLHS Kota Kendari. 2012. Revitalisasi Teluk Kendari dalam Kebijakan, Rencana dan Program (KRP). Kota Kendari, Provinsi Sulawesi Tenggara

Revised August 2019 